\title{
THE NITROGEN METABOLISM IN ANEMIA DURING THE REGENERATION OF BLOOD
}

\author{
By CLARK W. HEATH ANd F. H. L. TAYLOR \\ (From the Thorndike Memorial Laboratory, Second and Fourth Medical Services (Harvard), \\ Boston City Hospital and the Department of Medicine, Harvard Medical School, Boston)
}

(Received for publication March 16, 1936)

The present study was made following certain observations upon the plasma proteins in anemia. An attempt was made to explain the initial gain in weight (1) and the appearance of palpable edema in certain anemic patients as their blood improved. It was assumed that the increased need for protein substances in the building of new hemoglobin might result in a reduction of the plasma protein and of the plasma oncotic pressure when the diet contained a reduced amount of protein. No correlation between a reduction of the plasma protein and the appearance of palpable edema, however, was found, perhaps in part due to the fact that gains in weight and the development of edema did not occur to any considerable degree in the patients studied.

Marked changes in the nitrogen metabolism, however, have accompanied the regeneration of blood following the administration of effective material in various forms of anemia in this clinic. These changes manifest themselves as a reduction of the nonprotein nitrogen, plasma protein and nitrogen elimination. That this should be so was not remarkable in view of the considerable demand for protein for hemoglobin formation (for a gain of each 10 per cent in hemoglobin about 80 grams of protein are required). The anemic patient while regenerating hemoglobin, therefore, offered an opportunity to study the effect of sudden protein demand on the nitrogen metabolism of the organism. In addition to the theoretical information to be obtained from the study, it was hoped that points of therapeutic interest might emerge. In the present communication the effect of hemoglobin regeneration on nitrogen retention, on the plasma protein and nonprotein nitrogen, and on the tissue nitrogen is reported. In a subsequent communication the observations will be extended to variations in the remaining nitrogen partitives.

Nine severely anemic patients were chosen for study. The sex, age of these patients, together with the diagnoses of their cases, are given at the end of the communication. Regeneration of blood occurred during the period of observation in five patients with hypochromic anemia (Cases 1, 2, 4, 7 and 8) when iron was administered; in two patients with pernicious anemia (Cases 5 and 6 ) following administration of material specifically active in this condition; in one patient with scurvy (Case 9) following the administration of an adequate diet. Case 3, a patient suffering from hypochromic anemia, was given no medication during the period of observation and was used as a control. In addition to this case, the first twelve-day period of Case 7 was used as a control period, and no medication was given during this time.

The patients were given diets which were adequate in calories but were usually low in protein. Water and table salt were unrestricted. Urine was collected for three-day periods. In two instances stools were collected for three-day periods. Venous blood was collected usually every other day. Red blood cell counts and cell volume measurements were made upon this blood. The hemoglobin was measured by a Sahli instrument calibrated as described below. Reticulocytes were counted daily upon smears stained supravitally with brilliant cresyl blue. The blood volume was measured, usually every fourteen days, by means of the vital red technique as described by Rowntree, Brown and Roth (2).

All chemical analyses were made in duplicate. The plasma proteins were determined upon oxalated blood plasma by the Kjeldahl method, using the macro modification of Howe (3). Certain essential changes in the method were made as described by Peters and Van Slyke (4). The most important of these modifications are as follows: digestion of the plasma was accomplished by the use of $10 \mathrm{ml}$. of concentrated sulphuric acid 
low in nitrogen and 5 grams of a digestion mixture prepared by mixing 500 grams of potassium sulphate and 10 grams of powdered copper sulphate. Complete digestion was assured by the use of Merck's superoxol. Two hundredth normal hydrochloric acid and sodium hydroxide were employed in the titrations. Instead of methyl red, Tashirio's indicator was used in the titrations because of the sharper end-point obtained with acids and alkalis of the dilution used. The indicator was prepared following the suggestions of Kerr and Blish (5).

The nonprotein nitrogen and the urinary nitrogen were determined by the micro-chemical methods of Folin (6). Stools were collected in sulphuric acid, mixed to a homogeneous suspension, weighed, and aliquot samples taken for determination of nitrogen by the usual $\mathrm{Kjeldahl}$ method. The average daily stool nitrogen of Cases 3 and 8 and of two additional cases of anemia, not included in this series, was 0.7 gram. This figure was employed in calculating the nitrogen output in those cases in which fecal nitrogen was not determined. This seemed to be a fairer basis of calculation in this particular study than the normal range, which was found to be from 1.25 to 1.50 grams per day.

The plasma protein per cent, blood volume and hematocrit being known, the total circulating plasma protein or plasma nitrogen may be easily calculated. Because of the large number of chemical analyses and the considerable amount of blood which was drawn, analysis of circulating whole blood nitrogen was not made but was calculated from the hemoglobin readings and plasma protein values.

Sahli hemoglobinometers were calibrated in such a manner, employing blood upon which the oxygen capacity was known, that 100 per cent hemoglobin corresponded to an oxygen capacity of 20.9 volumes per $100 \mathrm{ml}$. of blood, and this was assumed to be the equivalent of 15.6 grams of hemoglobin per $100 \mathrm{ml}$. of blood.

Determinations of the nitrogen content of washed red blood cells and of hemolyzed red blood cells, free of plasma and stroma, were compared with the amount of hemoglobin ascertained from the Van Slyke oxygen capacity method. Nitrogen values were multiplied by 6.25 to obtain values for total protein (hemoglobin). In one normal individual and four patients with pernicious anemia the protein equivalents of hemolyzed red blood cells free of plasma and stroma, per 21 volumes of oxygen per cent, were respectively, 15.7, 15.7, 15.8, 15.0, 15.6 grams per 100 $\mathrm{ml}$, or an average of 15.6 grams per $100 \mathrm{ml}$. of blood. The determination of the hemoglobin nitrogen, therefore, gave results which were quite in keeping with the assumed weight of hemoglobin. The error introduced in determining total circulating nitrogen by not including the nitrogen of the stroma of the red blood cells and of the other formed elements of the blood was small and was disregarded in the present calculation. There is some evidence that the structure of the hemoglobin molecule may vary in different forms of anemia (7), but there is no evidence, as far as the authors can discover, that the nitrogen content or actual size of the hemoglobin molecule varies appreciably.

Since in Cases 7 and 8 there occurred losses of blood in the stools, it is important to consider what effect, if any, such losses have on the experimental findings. In all of the patients in whom loss of blood was responsible for the anemia, except Case 1, the loss of blood occurred in the upper gastro-intestinal tract. Under these circumstances it was considered probable that the protein and other nitrogenous constituents so lost from the blood stream were absorbed and utilized in the same manner as food protein. Such a state of affairs would occasion little loss of nitrogen to the organism. This assumption has been borne out by experimental data. It has been found from other studies that the characteristic low nitrogen content of the stools was maintained even in the face of chronic loss of blood from the upper gastro-intestinal tract. Carefully controlled experiments have shown no increased loss of nitrogen in the stools or in the distribution of the various nitrogenous partitives in the whole blood, blood plasma or urine even when the stools gave a markedly positive test for occult blood. Case 8, for example, was bleeding throughout the experiment from a cancer of the stomach, yet the daily output of nitrogen in the stools ( 0.7 gram) was in close agreement with that found in Case 6 in which there was no blood loss. 


\section{EXPERIMENTAL}

The summary of the experimental results are given in Tables I and II. Table II is included for the purpose of giving the experimental data on which Table I is based. In Table III and Figure 1 the results in a typical case are given. The results for Case 1 in Table I indicate gain or loss of circulating nitrogen somewhat higher than that which may be calculated from Table III. This is because the loss of nitrogen by venesection in Case 1 has been taken into account in the preparation of Table $I$ and appears as manufactured plasma and hemoglobin nitrogen. Inspection of the data in Tables I and II shows that hemoglobin was always formed in response to antianemic therapy, regardless of the extent or nature of nitrogen losses from the organism as a whole. The demand for nitrogen occasioned by this response was met in various ways, depending upon first, the level of the protein in the diet, and second the nutritional state of the patient.
When the nitrogen intake was below 6.2 grams per day, hemoglobin was manufactured at the expense of either the plasma nitrogen, the tissue nitrogen or both. If, however, the amount of nitrogen fed was above 6.2 grams per day, much of the required nitrogen was provided by the diet. Hemoglobin was always formed in response to therapy even in the presence of tissue and plasma nitrogen deprivation.

Cases 1, 4, 7 and 8 all show similar responses to nitrogen demand for hemoglobin regeneration and therefore may be conveniently discussed together. In all four cases the nitrogen intake was initially below 6.2 grams per day, and there was a slightly negative nitrogen balance of between 1 and 2 grams per day. It must be borne in mind, however, that this negative balance does not mean that the body was failing to minimize the loss of nitrogen in the urine during nitrogen demand. On the contrary, the daily loss of nitrogen in the urine in some of these cases was below the value generally

TABLE I

Summary of nitrogen metabolism in anemia during hemoglobin regeneration

\begin{tabular}{|c|c|c|c|c|c|c|c|c|c|c|c|c|}
\hline $\begin{array}{c}\text { Case } \\
\text { num- } \\
\text { ber }\end{array}$ & Diagnosis & Therapy & Period & $\begin{array}{c}\text { Num- } \\
\text { ber } \\
\text { of } \\
\text { days }\end{array}$ & $\begin{array}{c}\text { Aver- } \\
\text { age } \\
\text { daily } \\
\text { nitro- } \\
\text { gen } \\
\text { intake }\end{array}$ & $\begin{array}{c}\text { Total } \\
\text { nitro- } \\
\text { gen } \\
\text { intake }\end{array}$ & $\begin{array}{c}\text { Total } \\
\text { nitro- } \\
\text { gen } \\
\text { out- } \\
\text { put }\end{array}$ & $\begin{array}{c}\text { Nitro- } \\
\text { gen } \\
\text { balance }\end{array}$ & $\begin{array}{c}\text { Total } \\
\text { gain } \\
\text { of } \\
\text { nitro- } \\
\text { gen } \\
\text { in } \\
\text { plasma } \\
\end{array}$ & $\begin{array}{l}\text { Total } \\
\text { gain } \\
\text { of } \\
\text { nitro- } \\
\text { gen in } \\
\text { hemo- } \\
\text { globin }\end{array}$ & $\begin{array}{l}\text { Total } \\
\text { gain } \\
\text { of } \\
\text { nitro- } \\
\text { gen in } \\
\text { circu- } \\
\text { lation }\end{array}$ & $\begin{array}{c}\text { Total } \\
\text { gain } \\
\text { of } \\
\text { nitro- } \\
\text { gen } \\
\text { in } \\
\text { tissues }\end{array}$ \\
\hline \multirow{3}{*}{1.} & \multirow{3}{*}{$\begin{array}{l}\text { Hypochromic anemia, chronic loss of } \\
\text { blood (menorrhagia), hypochlor- } \\
\text { hydria. }\end{array}$} & \multirow{3}{*}{$\begin{array}{l}\text { Iron } \\
\text { Iron }\end{array}$} & \multirow{7}{*}{$\begin{array}{c}1 \\
2 \\
1 \text { and } 2\end{array}$} & & grams & grams & grams & grams & grams & grams & grams & grams \\
\hline & & & & $\begin{array}{l}24 \\
12\end{array}$ & $\begin{array}{r}4.0 \\
18.6\end{array}$ & $\begin{array}{r}95.9 \\
222.8\end{array}$ & $\begin{array}{l}123.6 \\
101.6\end{array}$ & $\begin{array}{r}-27.7 \\
+121.2 \\
\end{array}$ & $\begin{array}{r}-10.7 \\
+6.8\end{array}$ & $\begin{array}{l}+22.1 \\
+21.4\end{array}$ & $\begin{array}{r}+11.4 \\
+28.2\end{array}$ & $\begin{array}{l}-39.1 \\
+93.0\end{array}$ \\
\hline & & & & Total & 8.9 & 318.7 & 225.2 & +93.5 & -3.9 & +43.5 & +39.6 & +53.9 \\
\hline 2. & $\begin{array}{l}\text { Hypochromic anemia, duodenal ul- } \\
\text { cer, loss of blood. }\end{array}$ & Iron & & 27 & 7.3 & 195.9 & 174.8 & +21.1 & +1.0 & +30.3 & +31.3 & -10.2 \\
\hline 3. & $\begin{array}{l}\text { Hypochromic anemia, duodenal ul- } \\
\text { cer, loss of blood. }\end{array}$ & None & & 24 & 9.9 & 237.4 & 224.6 & +12.8 & -0.5 & +2.2 & +1.7 & +11.1 \\
\hline 4. & $\begin{array}{l}\text { Hypochromic anemia, duodenal ul- } \\
\text { cer, loss of blood. }\end{array}$ & Iron & & 39 & 6.1 & 232.6 & 277.2 & -44.6 & -22.5 & +47.2 & +24.7 & -69.3 \\
\hline 5. & Pernicious anemia. & $\begin{array}{c}\text { Potent } \\
\text { substance }\end{array}$ & & 39 & 6.4 & 247.7 & 231.2 & +16.5 & -2.1 & +50.4 & +48.3 & -31.8 \\
\hline \multirow[t]{2}{*}{6.} & \multirow[t]{2}{*}{ Pernicious anemia. } & \multirow[t]{2}{*}{$\begin{array}{c}\text { Potent } \\
\text { substance }\end{array}$} & $\mathbf{1}$ & $\begin{array}{l}57 \\
27\end{array}$ & $\begin{array}{r}6.5 \\
21.1\end{array}$ & $\begin{array}{l}373.5 \\
501.3\end{array}$ & $\begin{array}{l}321.2 \\
239.0\end{array}$ & $\begin{array}{r}+52.3 \\
+262.3\end{array}$ & $\begin{array}{l}-6.5 \\
-1.3\end{array}$ & $\begin{array}{l}+46.1 \\
+20.8\end{array}$ & $\begin{array}{l}+39.6 \\
+19.5\end{array}$ & $\begin{array}{r}+12.7 \\
+242.8\end{array}$ \\
\hline & & & 1 and 2 & Total & 11.6 & 874.8 & 560.2 & +314.6 & -7.8 & +66.9 & +59.1 & +255.5 \\
\hline \multirow[t]{2}{*}{7.} & \multirow[t]{2}{*}{$\begin{array}{l}\text { Hypochromic anemia, inoperable } \\
\text { cancer of stomach, chronic loss of } \\
\text { blood. }\end{array}$} & \multirow[t]{2}{*}{$\begin{array}{l}\text { None } \\
\text { Iron } \\
\text { Iron }\end{array}$} & $\begin{array}{l}1 \\
2 \\
3\end{array}$ & $\begin{array}{l}12 \\
39 \\
24\end{array}$ & $\begin{array}{l}3.6 \\
4.6 \\
9.0\end{array}$ & $\begin{array}{r}43.5 \\
178.1 \\
215.5\end{array}$ & $\begin{array}{r}57.3 \\
193.0 \\
137.1\end{array}$ & $\begin{array}{l}-13.8 \\
-14.9 \\
+78.4\end{array}$ & $\begin{array}{l}-0.1 \\
-4.0 \\
+1.7\end{array}$ & $\begin{array}{r}-0.8 \\
+27.5 \\
+4.3\end{array}$ & $\begin{array}{r}-0.9 \\
+23.5 \\
+6.0\end{array}$ & $\begin{array}{l}-12.9 \\
-38.4 \\
+72.4\end{array}$ \\
\hline & & & 1, 2 and 3 & Total & 5.8 & 437.1 & 387.4 & +49.7 & -2.4 & +31.0 & +28.6 & +21.1 \\
\hline \multirow[t]{2}{*}{8.} & \multirow{2}{*}{$\begin{array}{l}\text { Hypochromic anemia, inoperable } \\
\text { cancer of stomach, chronic loss of } \\
\text { blood. }\end{array}$} & \multirow[t]{2}{*}{$\begin{array}{l}\text { Iron } \\
\text { Iron }\end{array}$} & $\mathbf{1}$ & $\begin{array}{l}33 \\
15\end{array}$ & $\begin{array}{l}3.6 \\
8.3\end{array}$ & $\begin{array}{l}118.5 \\
124.1\end{array}$ & $\begin{array}{r}155.2 \\
69.5\end{array}$ & $\begin{array}{l}-36.7 \\
+54.6\end{array}$ & $\begin{array}{l}-3.6 \\
-1.7\end{array}$ & $\begin{array}{r}+24.7 \\
-8.4\end{array}$ & \pm 21.1 & $\begin{array}{l}-57.8 \\
+64.7\end{array}$ \\
\hline & & & 1 and 2 & Total & 5.1 & 242.6 & 244.7 & +17.9 & -5.3 & +16.3 & +11.0 & +6.9 \\
\hline \multirow[t]{2}{*}{9.} & \multirow[t]{2}{*}{ Scurvy, nutritional anemia. } & \multirow[t]{2}{*}{$\begin{array}{l}\text { Diet } \\
\text { Diet }\end{array}$} & $\mathbf{1}$ & 24 & $\begin{array}{r}6.3 \\
19.0\end{array}$ & $\begin{array}{l}151.5 \\
514.1\end{array}$ & $\begin{array}{r}70.4 \\
214.9\end{array}$ & $\begin{array}{r}+81.1 \\
+299.2\end{array}$ & -3.0 & $\begin{array}{l}+24.8 \\
+34.9\end{array}$ & $\begin{array}{l}+21.8 \\
+42.4\end{array}$ & $\begin{array}{r}+59.3 \\
+256.8\end{array}$ \\
\hline & & & 1 and 2 & Total & 13.1 & 665.6 & 285.3 & +380.3 & +4.5 & +59.7 & +64.2 & +316.1 \\
\hline
\end{tabular}


TABLE II

Initial and final values employed in the determination of the total circulating nitrogen

\begin{tabular}{|c|c|c|c|c|c|c|c|c|c|}
\hline \multirow{2}{*}{$\begin{array}{c}\text { Case } \\
\text { number }\end{array}$} & \multicolumn{2}{|c|}{ Hemoglobin } & \multicolumn{2}{|c|}{$\begin{array}{l}\text { Plasma } \\
\text { protein }\end{array}$} & \multicolumn{2}{|c|}{$\begin{array}{c}\text { Blood } \\
\text { volume }\end{array}$} & \multicolumn{2}{|c|}{$\begin{array}{l}\text { Plasma } \\
\text { volume }\end{array}$} & \multirow{2}{*}{$\begin{array}{l}\text { Blood } \\
\text { lost by } \\
\text { vene- } \\
\text { section }\end{array}$} \\
\hline & Initial & Final & Initial & Final & Initial & Final & Initial & Final & \\
\hline & $\begin{array}{c}\text { orams } \\
\text { per } \\
100 \\
\text { ml }\end{array}$ & $\begin{array}{c}\text { orams } \\
\text { per } \\
100 \\
\mathrm{ml}\end{array}$ & $\begin{array}{c}\text { grams } \\
\text { per } \\
100 \\
\text { ml }\end{array}$ & $\begin{array}{c}\text { grams } \\
\text { per } \\
100 \\
\text { l }\end{array}$ & $m l$. & $m l$. & $m l$. & $m l$. & $m l$. \\
\hline $\begin{array}{l}\text { 1. Ly...... } \\
\text { 2. Kn...... } \\
\text { 3. Bu...... } \\
\text { 4. La...... } \\
\text { 5. Mas..... } \\
\text { 6. Mac..... } \\
\text { 7. Da...... } \\
\text { 8. Be...... } \\
\text { 9. Ha...... }\end{array}$ & $\begin{array}{l}4.8 \\
8.9 \\
6.9 \\
5.6 \\
6.2 \\
5.5 \\
7.6 \\
5.5 \\
9.4\end{array}$ & $\begin{array}{r}10.8 \\
12.0 \\
7.5 \\
11.5 \\
11.9 \\
14.5 \\
11.7 \\
6.8 \\
15.1\end{array}$ & $\begin{array}{l}\mathbf{7 . 1 5} \\
\mathbf{5 . 5 4} \\
\mathbf{6 . 0 5} \\
\mathbf{7 . 0 0} \\
\mathbf{5 . 7 2} \\
\mathbf{6 . 2 1} \\
\mathbf{6 . 0 2} \\
\mathbf{5 . 8 2} \\
\mathbf{5 . 4 1}\end{array}$ & $\begin{array}{l}\mathbf{7 . 3 6} \\
\mathbf{5 . 4 8} \\
\mathbf{6 . 4 0} \\
\mathbf{6 . 1 3} \\
\mathbf{6 . 0 4} \\
\mathbf{5 . 6 5} \\
\mathbf{5 . 7 0} \\
\mathbf{4 . 8 9} \\
\mathbf{6 . 6 0}\end{array}$ & $\begin{array}{l}\mathbf{4}, 000 \\
\mathbf{3}, \mathbf{3 4 0} \\
\mathbf{5}, 140 \\
\mathbf{6 , 2 3 0} \\
\mathbf{4}, \mathbf{5 2 0} \\
\mathbf{3 , 8 4 0} \\
\mathbf{3 , 5 5 0} \\
\mathbf{3 , 6 2 0} \\
\mathbf{3 , 7 6 0}\end{array}$ & $\begin{array}{l}\mathbf{4}, 090 \\
\mathbf{3}, 880 \\
4,690 \\
\mathbf{5 , 4 2 0} \\
\mathbf{4 , 9 3 0} \\
\mathbf{3 , 8 8 0} \\
\mathbf{3 , 4 4 0} \\
\mathbf{3 , 5 7 0} \\
\mathbf{4 , 3 6 0}\end{array}$ & $\begin{array}{l}3,240 \\
2,400 \\
3,930 \\
4,900 \\
3,680 \\
3,220 \\
2,680 \\
2,880 \\
2,730\end{array}$ & $\begin{array}{l}2,580 \\
2,390 \\
3,540 \\
2,760 \\
3,060 \\
2,160 \\
2,130 \\
2,550 \\
2,380\end{array}$ & $\begin{array}{l}325 \\
200 \\
180 \\
350 \\
280 \\
740 \\
640 \\
355 \\
\mathbf{5 0 0}\end{array}$ \\
\hline
\end{tabular}

accepted as the irreducible nitrogen elimination occasioned by normal tissue catabolism and basal metabolic processes. Actually these patients show for long periods of time a considerable reduction of the nitrogen output in the urine which can persist for weeks after the blood has returned to normal. Thus, one of the first responses of hemoglobin demand in the cases investigated is a diminution of nitrogen constituents of the urine.

In the four cases under discussion nitrogen
TABLE III

Case 1. (Ly.) Chronic loss of blood (menorrhagia). Hypochlorhydria

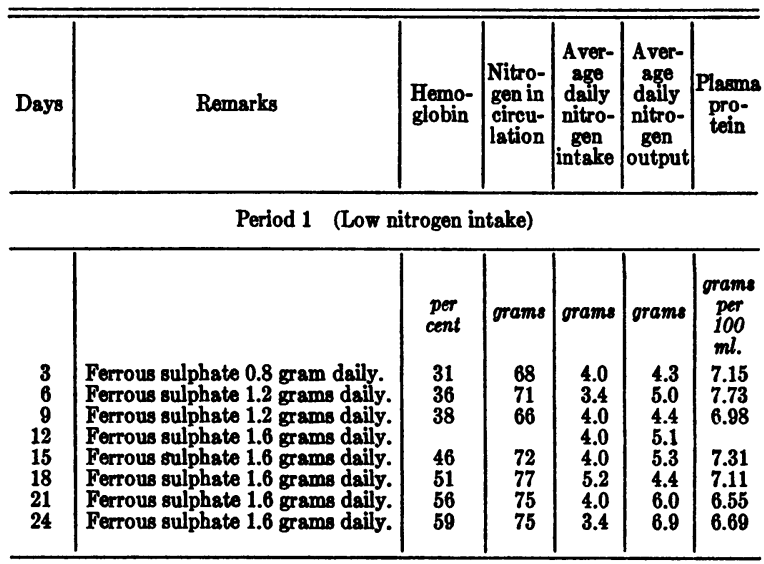

Period 2 (High nitrogen intake)

\begin{tabular}{l|l|l|r|r|r|r}
\hline 27 & Ferrous sulphate 1.6 grams daily. & 64 & 84 & 18.2 & 8.3 & 6.63 \\
30 & Ferrous sulphate 1.6 grams daily. & 60 & 87 & 17.8 & 6.7 & 6.47 \\
33 & Ferrous sulphate 1.6 grams daily. & 66 & 96 & 19.2 & 10.2 & 7.26 \\
36 & Discharged. High protein diet. & 69 & 101 & 19.1 & $\mathbf{8 . 7}$ & $\mathbf{7 . 3 6}$ \\
49 & Ferrous sulphate 1.6 grams daily. & 77 & 107 & & & $\mathbf{7 . 1 4}$ \\
\hline
\end{tabular}

spared from urinary excretion was not sufficient to satisfy the demands of the hemoglobin building centers. Instead of the production of hemoglobin

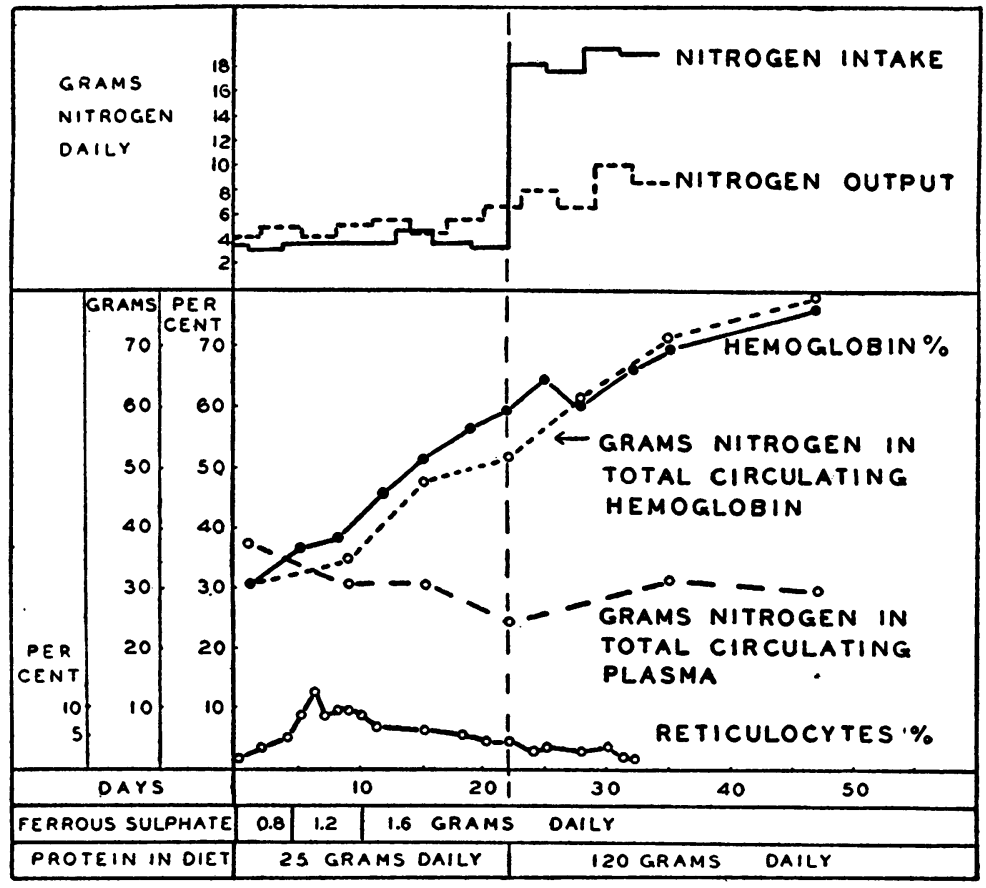

Fig. 1. Case 1 (Ly). The Nitrogen Balance and the Nitrogen of the Circulation during Hemoglobin Regeneration 
being slowed under these circumstances, as was at first expected, it proceeded at the same normal rate (about 1 gram of hemoglobin nitrogen per day). The nitrogen required for this purpose was furnished by the nitrogen of the plasma protein and of the tissues. For example, there was usually a fall in the total circulating plasma nitrogen as the hemoglobin rose. This is strikingly illustrated by Case 1 (see Figure 1, and Tables I and III). For the sake of brevity the corresponding tables and figures for the other three cases are not given but data may be calculated from that given in Tables I and II.

In three of the four cases under discussion (Cases $1,7,8$ ) the period of low protein diet was followed by one of normal or even high protein diet. The results confirmed the findings that there had been marked deprivation of tissue nitrogen during the period of low protein intake and hemoglobin regeneration. With the increase of nitrogen in the diet there occurred a marked nitrogen retention. Coincident with this nitrogen retention the drain on the nitrogen of the circulating plasma and of the tissues ceased. Of the four cases, Case 1 is probably the most significant in this regard since the increase in nitrogen intake took place at a time when the hemoglobin was still being formed at a rapid rate. It will be observed from Table III and Figure 1 that with the increase in nitrogen intake the patient was able to manufacture hemoglobin and at the same time slowly to replace the nitrogen deficit in the circulating plasma.

The limiting condition between the first type of response to hemoglobin formation and the type of response in the remaining cases seems to be the level of the protein intake. If the nitrogen intake was below 6.2 grams per day a positive nitrogen balance never occurred in patients with anemia during their response to antianemic material. The amount of nitrogen fed two patients (Cases 2 and 5) was above this critical level, namely, 7.3 and 6.4 grams, respectively. The effect of hemoglobin regeneration on the nitrogen metabolism of these two patients differed in degree rather than in kind from the patients of the first group. In the first group, with a negative nitrogen balance, the tissue protein and plasma nitrogen satisfied the demand for nitrogen occasioned by hemoglobin formation; in Cases 2 and 5 a portion of the nitro- gen was definitely provided for by the increased retention of nitrogen, and the tissue and plasma nitrogen were to some extent spared. This is well illustrated in a comparison of Case 4 with Case 5 . In Case 4, 47 grams of hemoglobin nitrogen were produced in 39 days in the face of a negative nitrogen balance of 45 grams. To provide the required nitrogen the tissues contributed 69 grams and the plasma 22.5 grams. In Case 5 over the same period of time 50 grams (or approximately the same amount as in Case 4) of hemoglobin nitrogen were manufactured in the presence of a positive nitrogen balance of 16.5 grams. The total cost to the organism in this case was only 32 grams of tissue nitrogen and 2 grams of plasma nitrogen.

The effect of nitrogen retention is even more marked in two other cases (Cases 6 and 9). The demands of nitrogen for hemoglobin manufacture in these patients were met by the nitrogen retained from the food with a small contribution from the plasma. The tissues in these two cases were enabled to lay down nitrogen. The two cases showing this response differ in one important regard from the other cases. Both patients suffered from extreme nitrogen deprivation. Indeed, it is doubtful if the tissues could have contributed to an increased nitrogen demand. Experimentally, it was found in Case 6, for example, when the protein intake was much increased, over 1500 grams of protein were laid down in the tissues. In spite of this enormous protein deficit the organism readily spared 46 grams of nitrogen for the manufacture of hemoglobin while the intake of protein was low (Table I, Case 6, Period 1). The requirements of the body for hemoglobin seemed to be greater than those for tissue protein. One fact not shown in the tables must be pointed out in connection with this patient (Case 6). The nitrogen balance did not become positive until after response to anti-pernicious anemia substance was instituted. In short, this patient responded to increased nitrogen demand by still further increasing his nitrogen retention.

The course of events in the second patient (Case 9, Table I), was similar. Here, however, we have unequivocal evidence from the dietary history that tissue starvation had advanced to an alarming degree. Under adequate dietary therapy, without liver or iron, and with a nitrogen 
intake of 6.4 grams per day, hemoglobin regeneration occurred. To provide for this additional nitrogen requirement, the nitrogen output in the urine fell to the very low figure of 2 grams a day. For the purpose of giving significance to this statement one may observe for comparison Cases 4 and 5, Table I. These two cases, in which the nitrogen intake was approximately the same, and in which a somewhat faster rate of hemoglobin regeneration occurred than in Case 9, still were able to excrete between 4 and 6 grams of nitrogen daily. Thus hemoglobin demand for nitrogen was provided to a considerable extent from tissue and plasma nitrogen in these cases. In Case 9, however, plasma, hemoglobin and tissue nitrogen were provided by the diet alone in the presence of an exceedingly small nitrogen output.

It will be seen from the foregoing discussion that the body will manufacture hemoglobin under the spur of antianemic substances regardless of the source of the necessary nitrogen. The three responses given above are really different quantitative aspects of the same phenomenon. Which type of response will occur depends upon the level of protein fed, the extent of the hemoglobin demand, and the nutritional state of the organism.

Changes in other factors which have been studied in this series of nine anemic cases will be considered briefly: (1) the albumin and globulin values of the plasma, and (2) the nonprotein nitrogen of the plasma.

The albumin and globulin values of the plasma. The albumin content of the plasma was usually below 4.0 grams per $100 \mathrm{ml}$. On the other hand, the globulin was scarcely ever reduced below normal (1.4 grams per $100 \mathrm{ml}$.). In only one case (Case 1) was the globulin above 3.0 grams per $100 \mathrm{ml}$. plasma. Diminution in the total plasma protein during the observations seemed to be usually at the expense of the albumin fraction, the globulin fraction, as a rule, remaining constant. A reduction of the concentration of the plasma proteins could not usually be demonstrated when the need for protein was increased by hemoglobin regeneration, unless the diet contained abnormally small amounts of protein.

Plasma nonprotein nitrogen. A striking feature was a very marked reduction of the plasma nonprotein nitrogen in all cases during hemoglobin regeneration. The values reached levels below 20 mgm. per $100 \mathrm{ml}$. in every case. The lowest recorded values were 14.2 and $14.6 \mathrm{mgm}$. per 100 $\mathrm{ml}$. in Cases 5 and 8 respectiveiy. The decrease in the nonprotein nitrogen seemed to occur regardless of whether or not there was a decrease of the plasma protein concentration or of the total circulating plasma nitrogen. The values increased again in those cases receiving high protein diets. Increased need for nitrogenous constituents of the circulating plasma during blood regeneration is believed to be responsible for the reduction in the nonprotein nitrogen.

\section{COMMENT}

It does not seem illogical to assume that in these patients the plasma acted as a vehicle for the transportation and provision of the nitrogen necessary for hemoglobin and cell formation. It may well be that the passage of nitrogen from the tissues to the plasma and so to the hematopoietic centers is considerably greater than the losses of nitrogen from the plasma which are recorded in Table I. The idea of Holman, Mahoney and Whipple (8) from observations in dogs that there is a "give and take" between the tissue proteins and the plasma proteins, seems to have evidence in its favor in these clinical observations.

That there is a tendency to a large conservation of nitrogenous substances in the body, when hemoglobin regeneration takes place, is a fact which has been noted by others (9). Holman, Mahoney and Whipple (10) have demonstrated that there is a large reserve of protein-building substances in the body which can be used to replenish exhausted circulating plasma protein. Presumably, this reserve of protein-building substances can even more readily be employed for hemoglobin formation.

Special comment should be made upon the patient with scurvy (Case 9) who suffered not only from anemia but also from a marked deficiency of nitrogenous substances, as exemplified by the reduced plasma protein, the massive edema, and the markedly positive nitrogen balance throughout the period of observation. It is interesting to speculate upon the conditions which led up to this patient's deficiency in nitrogenous substances. His dietary intake for four years is 
quite accurately known, since he partook meticulously during this period of practically only crackers and milk. His diet contained about $1600 \mathrm{cal}-$ ories and about 70 grams of protein or about 11 grams of nitrogen daily. With this intake, he must have had a negative nitrogen balance during at least a good part of the time. Nevertheless, when reparative processes set in, following the administration of a diet adequate in calories and vitamins, it is conceivable that he could have been in nitrogen balance receiving as little as 2 grams of nitrogen daily. It can be inferred from this that vitamin $\mathrm{C}$ may play a part in normal tissue protein metabolism, just as it seems to play a part in hemoglobin anabolism.

The practical implication of the results of the present observations is, of course, that in the treatment of anemic patients, attention should be directed to the protein of the diet. Many patients with anemia appear to have a deficient store of nitrogenous substances, and when there is an additional demand on these substances for hemoglobin production the store may be even more depleted. There is no question, however, that there is an additional store of protein substances in the hyperplastic bone marrow of cases of pernicious anemia and chronic iron deficiency. In these conditions there is arrested maturation of nucleated red blood cells, which may fill the marrow spaces of the long bones. The bone marrow, however, can provide probably only a fraction of the necessary nitrogen since in its entirety it is considerably smaller than the volume of the circulating red blood cells (11).

Payne and Peters (12) have presented the idea that a loss of protein into serous effusions in cardiac patients may contribute to edema formation by reduction of the effective osmotic pressure. The concept of an intrinsic loss of body protein by alterations in the internal environment is not new, and is a proposition which must be borne in mind in the management of many types of patients.

\section{CONCLUSIONS}

1. Hemoglobin formation is accompanied by a positive nitrogen balance, only when the diet contains somewhat more than 6.2 grams nitrogen per day.
2. Hemoglobin formation, however, proceeds at a normal rate even in the face of a negative nitrogen balance.

3. The demand for nitrogen under these circumstances seems to be supplied by tissue and plasma nitrogen.

4. With diets low in protein, extremely low values for daily nitrogen excretion may be observed during blood regeneration, and a reduction of the plasma nonprotein nitrogen is characteristic.

5. The blood plasma seems to play an important rôle in the storage and transportation of nitrogenous substances.

6. In the treatment of anemia a diet adequate in protein is necessary in order to replace tissue nitrogen which may have become diminished before or during hemoglobin regeneration.

\section{DESCRIPTION OF CASES}

Case 1 (Ly). Female, age 42 years. Hypochromic anemia, chronic loss of blood (menorrhagia), hypochlorhydria, inadequate diet.

Case $2(\mathrm{Kn})$. Male, age 42 years. Hypochromic anemia, duodenal ulcer, subacute loss of blood.

Case $3(\mathrm{Su})$. Male, age 21 years. Hypochromic anemia, duodenal ulcer, subacute loss of blood.

Case 4 (La). Male, age 30 years. Hypochromic anemia, duodenal ulcer, subacute loss of blood.

Case 5 (Maz). Male, age 41 years. Pernicious anemia.

Case 6 (Mac). Male, age 52 years. Pernicious anemia.

Case 7 (Da). Male, age 82 years. Hypochromic anemia, chronic loss of blood, pulmonary tuberculosis (arrested), diverticulum of esophagus, carcinoma of the stomach (inoperable).

Case $8(\mathrm{Be})$. Female, age 72 years. Hypochromic anemia, chronic loss of blood, carcinoma of stomach (inoperable), sensitive carotid sinus.

Case $9(\mathrm{Ha})$. Male, age 73 years. Normocytic anemia, scurvy, malnutrition, duodenal ulcer.

The authors gratefully acknowledge the technical assistance of Margaret A. Adams and Elizabeth F. King.

\section{BIBLIOGRAPHY}

1. Vaughan, J. M., The gain in body weight associated with remissions in pernicious anemia. Arch. Int. Med., 1931, 47, 688.

2. Rowntree, L. G., Brown, G. E., and Roth, G. M., 
The Volume of the Blood and Plasma in Health and Disease. W. B. Saunders Company, Philadelphia and London, 1929.

3. Howe, P. E., The determination of proteins in blood -A micro method. J. Biol. Chem., 1921, 49, 109.

4. Peters, J. P., and Van Slyke, D. D., Quantitative Clinical Chemistry. Vol. II. Methods. Williams \& Wilkins Company, Baltimore, 1932, p. 691.

5. Kerr, S. E., and Blish, M. E., A method for the determination of nucleotides in blood and muscle. J. Biol. Chem., 1932, 98, 193.

6. Folin, O., Laboratory Manual of Biological Chemistry. D. Appleton \& Company, New York and London, 1926, 4th ed.

7. Lang, K., Uber die Zusammensetzung des Globins bei gesunden und anämischen Menschen. Arch. f. exper. Path. u. Pharmakol., 1933, 174, 63.
8. Holman, R. L., Mahoney, E. B., and Whipple, G. H., Blood plasma protein given by vein utilized in body metabolism. II. A dynamic equilibrium between plasma and tissue proteins. J. Exper. Med., 1934, 59, 269.

9. Alt, H. L., The metabolism in pernicious anemia. Arch. Int. Med., 1929, 43, 488.

10. Holman, R. L., Mahoney, E. B., and Whipple, G. H., Blood plasma protein regeneration controlled by diet. I. Liver and casein as potent diet factors. J. Exper. Med., 1934, 59, 251.

11. Witts, L. J., The pathology and treatment of anaemia. Lancet, 1932, 222, 495.

12. Payne, S. A., and Peters, J. P., The plasma proteins in relation to blood hydration. VIII. Serum proteins in heart disease. J. Clin. Invest., 1932, 11, 103. 